\title{
CZY POTRZEBNE JEST NAM SACRUM? DIAGNOZA KULTURY W UJĘCIU LESZKA KOLAKOWSKIEGO
}

W artykule podjęto problematykę sekularyzacji i desakralizacji współczesnego życia społecznego. Krótko opisuje się w nim przyczyny podziału rzeczywistości na sacrum i profanum, odnosząc się w analizie do tekstów Leszka Kołakowskiego. Opracowanie jest próbą podsumowania konsekwencji, do jakich prowadzi zacieranie się różnic między tym, co stanowi sferę sacrum, a tym, co wskazuje na profanum.

Słowa kluczowe: Sacrum, profanum, Leszek Kołakowski, kultura.

\section{WPROWADZENIE}

Problematyka sekularyzacji i desakralizacji nie wydaje się z jednej strony niczym nowym, z drugiej jednak wskazuje na inny obszar zjawisk niż dotychczas klasyfikowane jako sakralne bądź pozasakralne. Świat jest strukturą dynamiczną, dlatego przedmioty czy zjawiska zakwalifikowane do sfery tego, co święte, moga po pewnym czasie znaleźć się poza kręgiem zainteresowań badaczy. „Niektóre przedmioty, wcześniej święte, dostają się do sfery profanum, natomiast rzeczy wcześniej świeckie zostają uświęcone"2. Próba zdefiniowania tych pojęć, a także odpowiedzi na pytania dotyczące genezy zjawiska oraz konsekwencji zacierania granic między sacrum a profanum to cel tego artykułu. Rozważania warto jednak rozpocząć od zdefiniowania pojęć.

\section{SACRUM A PROFANUM}

Podział na sacrum i profanum panuje przede wszystkim w myśli religijnej, jednak nie tylko. Z zagadnieniem tym zmagają się także filozofowie, psychologowie, a także wszyscy ci, którym nieobcy jest namysł nad kulturą. Pojawiają się jednak liczne wątpliwości dotyczące zakresu tych pojęć. Podział ten wydaje się bardzo trudny do ujęcia szczególnie w kategoriach filozoficznych. Jest to podział raczej intuicyjny i dotyczy kategorii kulturalnych, a nie poznawczych. Kiedy wykonujemy czynności codzienne: mycie, jedzenie, pracę, to dotyczą one sfery niesakralnej, kiedy idziemy zaś do świątyni, to pojawia się sfera świętości. Oto podział, który może odzwierciedlać poczucie ludzkie, przynajmniej dużej części osób, na poziomie czysto kulturalnym i obyczajowym ${ }^{3}$. Jednak nadal warto pamiętać, że poczucie tego, co święte, oraz przekonanie o jego przeciwieństwie będą uwarunkowane kulturowo, światopoglądowo oraz wyznaniowo. „Ruchy ciała - dla jogina, należące do sfery sacrum, dla protestanta będą należeć do sfery

\footnotetext{
${ }^{1}$ Dr Justyna Stecko, Zakład Nauk Humanistycznych, Wydział Zarządzania, Politechnika Rzeszowska.

${ }^{2}$ J. Audinet, Religia, miejsce pojawienia się odmienności, [w:] Encyklopedia religii świata, t. II, Wydawnictwo Akademickie Dialog, Warszawa 2002, s. 2055.

${ }^{3}$ L. Kołakowski, W salonie profesora Dudka, „Odra” 2003/6, s. 25.
} 
profanum. Używane instrumenty muzyczne i określone style śpiewu w Kościele Boga w Chrystusie, uważane będą za formę wyrażania kultu, za grzeszne natomiast w Kościele Chrystusa".

Pojawia się pytanie, kiedy ujawnił się dualizm: sacrum - profanum. Jedno z najbardziej popularnych rozwiązań wskazuje na sekularyzację jako zjawisko, którego początku można się doszukiwać dopiero w czasach oświecenia. Kołakowski idzie o krok dalej, mówiąc wprost, że dualizm ten jest w dużym stopniu efektem oświeceniowych koncepcji. Wcześniej taki podział nie miał sensu, ponieważ nic nie było religijnie obojętne: albo służyliśmy Bogu, albo diabłu, innej możliwości nie było ${ }^{5}$. Oświecenie dokonało desakralizacji życia, krytykowano podporządkowanie Bogu i Kościołowi. Najważniejszym celem człowieka miało być spożytkowanie swoich możliwości intelektualnych $\mathrm{i}$ uświadomienie sobie swojej wolności i niezależności. Zaczęło dominować przekonanie, że świat nie kryje już żadnej tajemnicy, a pojęcie Boga można zastapić pojęciem człowieka. Zaszły dwa równoczesne, ale różne procesy ${ }^{6}$. Pierwszy, zgodnie $\mathrm{z}$ oryginalnym znaczeniem tego słowa, nazywany bywa sekularyzacja. Sekularyzacja to pojęcie, które choć ostatnio wyraźnie nadużywane, warto uściślić jego definicję, ponieważ bywa różnie rozumiane. „Dla Hegla pojęcie sekularyzacji było tożsame $\mathrm{z}$ wolnością; dla przeciętnego fizyka oznacza ono, że to nie Bóg stoi za eksperymentem; dla malarza - czasem, że stracił dobrego klienta, częściej, że może malować, co mu się żywnie podoba; dla większości Polaków - że zaraz po Mszy niedzielnej mogą iść na zakupy"7. Dla Kołakowskiego zaś pojęcie to określa zjawisko oddzielenia religii od życia politycznego. Drugi z procesów przebiegał w obszarze wierzeń oraz kultury i możn nazwać go za Maxem Weberem odczarowaniem, bądź desakralizacją, czyli „usunięciem ze świata pierwiastka magicznego". Konsekwencją tego procesu był i wydaje się, że ciaggle jest, zanik religii, a także praktyk z nią związanych. W jednym z referatów wygłoszonych na konferencji „Religijność w dobie popkultury" ${ }^{\prime 9}$ pojawiła ciekawa ilustracja współczesnego aspektu desakralizacji. Była to analiza zjawiska sprzedaży kościołów i ich zamiany na miejsca użyteczności publicznej. Część sprzedanych budynków zamieniono na budynki mieszkalne, muzea, sale koncertowe, a nawet na skateparki, restauracje i bary. Od czasu restrukturalizacji diecezji Buffalo, rozpoczętej w 2005 roku, sprzedano 18 z 77 kościołów, natomiast na aukcjach internetowych bądź $\mathrm{w}$ ofertach agencji handlu nieruchomościami można znaleźć atrakcyjne oferty sprzedaży kościołów między innymi kościół św. Józefa w stanie Pensylwania za 199 tysięcy dolarów, czy też obiekt w Nowym Jorku za 99 tysięcy oraz budynek sakralny w Spencer (Ohio) za jedyne 97 tysięcy ${ }^{10}$.

\footnotetext{
${ }^{4}$ E. W. Rothenbuhler, Komunikacja rytualna: od rozmowy codziennej do ceremonii medialnej, Kraków 2003, s. 41.

${ }^{5}$ Por. L. Kołakowski, op. cit., s. 24.

${ }^{6}$ Por. D. Bell, Powrót sacrum. Tezy na temat przyszłości religii, thum. W. i K. Doroszowie, „Znak” 1983/9, s. 1378-1380.

${ }^{7}$ P. Nowak, Na poczatku byt Kolakowski, Tygodnik Powszechny, 2008/7.

${ }^{8}$ D. Bell, op. cit., s. 1379.

${ }^{9}$ Konferencja organizowana przez UKSW 16 grudnia 2010, tematem przewodnim była: „Religijność w dobie popkultury".

${ }^{10}$ Między innymi agencja nieruchomości: www.churchpropertylocator.com, cyt. za: http://stacjakultura.pl/1,4,4946,Kosciol_na_sprzedaz_oblicza_desakralizacji_cz_I,1,artykul.html (dostęp: 10 III 2012).
} 
Zarówno zjawisko sekularyzacji, jak i desakralizacji, różnorodnie rozumiane, nie wykluczają się wzajemnie, a można nawet zauważyć ich wzajemne warunkowanie. Czy jednak proces sekularyzacji pociagał za sobą zjawisko desakralizacji, czy też odwrotnie, pozostawiam bez odpowiedzi.

Kołakowski wskazuje na bezpośrednie, religijne uwarunkowanie pojęcia sacrum i choć jego koncepcja bywa nazywana anachroniczną ${ }^{11}$, wydaje się ciagle pomocna $\mathrm{w}$ analizie zagadnień sakralnych. Zdaniem myśliciela, ważnym aspektem zagadnienia sekularyzacji jest analiza tego zjawiska na płaszczyźnie chrześcijańskiego świata kultury, która może przebiegać dwojako. Jedną $\mathrm{z}$ dróg jest bezpośrednia negacja sacrum, zakwestionowanie istnienia jakiejkolwiek transcendencji, a co za tym idzie - świętości w ogóle. Drugie z wyjść wskazuje na uniwersalizację świętości, na zatarcie granicy między tym, co święte, i nieświęte. Jeżeli każdy nasz czyn wpiszemy w porządek Opatrzności i zamysłu Boga, zanegujemy sferę profanum. Powiedzieć, że wszystko jest święte, to tyle samo, co stwierdzić, że nic nie jest święte. Jedna i druga droga prowadzą do tych samych wyników. Przykładem, jaki przytacza Kołakowski, jest filozofia Teilharda de Chardin. „Jest to chrześcijaństwo, które całkowicie odrywa się od swoich źródeł apokaliptycznych, chrześcijaństwo, które śpieszy się uświęcać z góry wszystkie formy życia świeckiego, jako że wszystkie mogą uchodzić za krystalizację boskiej energii; chrześcijaństwo bez zła [...]" ${ }^{\prime 2}$. Kołakowski złośliwie stwierdza, że chrześcijaństwo podejmuje „wysiłek mimikry", starając się przybierać barwy otoczenia, i zamiast ocalenia sprowadza na siebie zagładę. Ponieważ tożsamość religii wspiera się na odróżnieniu sacrum i profanum. Nieco inaczej wyglądały czasy średniowiecza. Jednak rozróżnienie to istniało nie za sprawą kapłanów, ale naukowców, którzy starali się uniezależnić naukę od teologii, od nadzoru kościelnego. Być może więc teraz kapłani powinni reagować i zadbać o sakralny element fundamentu. Kołakowski mówi wprost o tym, że odpowiedzialnych za współczesny rozpad chrześcijaństwa powinniśmy poszukiwać wśród duchownych ${ }^{13}$. W świecie, $\mathrm{z}$ którego świętość zostanie wyrzucona, pozostaną zdaniem Kołakowskiego tylko dwie możliwości, ,[...] wybór proponowany przez Baudelaire'a: kochankowie prostytutek i kochankowie obłoków; ci którzy znają wyłącznie satysfakcję chwili i z tej racji zasługuja na pogardę, i ci którzy zatracają się w leniwej imaginacji i tym samym zasługują na

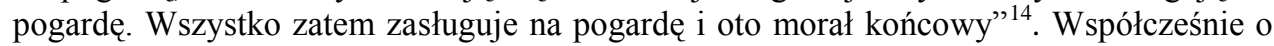
tego rodzaju zjawisku nie można już mówić jak o czymś hipotetycznym, ale jak najbardziej realnym. Dookoła można postrzegać zacieranie różnicy między sacrum a profanum. Zdaniem religioznawców, jednym $\mathrm{z}$ przejawów tego zjawiska jest desakralizacja świąt między innymi Bożego Narodzenia. Dla ogromnej rzeszy ludzi święta rozpoczynają się w galeriach i supermarketach, a kończą na Wigilii, coraz częściej można również spotkać się ze zjawiskiem komercjalizacji świąt oraz - jak określają to socjologowie - sakro-kiczu.

„Zagubiona sakralność świata pozostaje nieodżałowana. Na własną miarę wytwarzana przez współczesne instytucje religijne jest karykaturą - próbą wygenerowania z siebie

\footnotetext{
${ }^{11}$ J. Sieradzan, Sacrum i profanum czy sacrofanum? Przemiany w rozumieniu sacrum we wspótczesnym świecie, „Polskie Towarzystwo Ludoznawcze” 2006/90, s. 13-36.

${ }_{12}^{12}$ L. Kołakowski, Odwet sacrum w kulturze świeckiej, [w:] Czy diabet może być zbawiony i 27 innych kazań, Londyn 1982, s. 169.

${ }^{13}$ Por. L. Kołakowski, Moje wróżby w sprawie przyszłości religii i filozofii, [w:] Mini wykłady o maxi sprawach, t. III, Kraków 2000.

${ }^{14}$ L. Kołakowski, Odwet sacrum w kulturze świeckiej..., s. 173.
} 
czegoś, co z natury powinno być odkryciem, olśnieniem, kontemplacją. Żaden tradycjonalista, choćby się uparł przy trumnach na pogrzebie ( $\mathrm{w}$ sprzeciwie wobec kremacji zwłok), tyłem do ludzi odprawianej mszy świętej, komunii do ust - nie wygeneruje sacrum, które przepadło. Pozostało być może w sztuce, w muzyce, tej najszlachetniejszej, która zaklina coś nieuchwytnego"15.

Konsekwencją zacierania różnic między tym, co stanowi sferę sacrum, a tym, co wskazuje na profanum, jest także zamglenie granic między takimi pojęciami, jak wojna i pokój, suwerenność i niewola, inwazja i wyzwolenie, kat i ofiara, równość i despotyzm, prawo i gwałt, zwycięstwo i porażka, nauczyciel i uczeń, rozum i błazeństwo [...]"16. Dzieje się tak dlatego, że odpychając sacrum, odpychamy też granice, które nas określają. Jedynie za pośrednictwem sacrum - zdaniem Kołakowskiego - jesteśmy w stanie zidentyfikować zło. To jedyny system odniesienia, jedyne kryterium, które pozwala odróżnić dobro od zła ${ }^{17}$.

Ludzkie istnienie cechuje i powinno cechować nieprzezwyciężalne napięcie między sacrum a profanum, między porządkiem animalnym a porządkiem mitycznym, doczesnym a sakralnym, między koniecznością biologii a metafizycznymi ideami, między postawą błazna a kapłana. W różnych tekstach Kołakowski pokazuje liczne aspekty tego konfliktu, jednak sprowadza je on do owego nigdy nieusuwalnego napięcia, które nie tylko można zauważyć w rzeczywistości, ale w każdym człowieku. „Antynomie nie rozwiązują się, lecz pomagają nam dalej stawiać pytania nierozstrzygalne i wieść nasze życie z dala od nihilistycznej rozpaczy"18. Widoczne są tu ponownie inspiracje Pascalem. Napięcie między sacrum a profanum jest konstytutywne dla istoty człowieka.

Zacieranie granic prowadzi do jeszcze jednego, według Kołakowskiego, niezwykle istotnego niebezpieczeństwa: do złudzenia, że życie ludzkie nic nie ogranicza, że człowiek jest doskonale plastyczny. Złudzenie to - propagowane zarówno przez Nietzschego, jak i Sartre'a - zamiast ,[...] otworzyć przed człowiekiem perspektywę boskiego samotworzenia, zawiesza go w ciemności”"19. Dzieje się tak dlatego, że ,,[...] jeśli bieg wszechświata i spraw ludzkich nie ma żadnego sensu odniesionego do

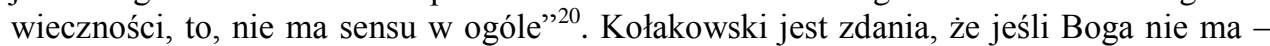
jak pisał Dostojewski - to może się okazać, że wszystko wolno. I nie jest to próba prowokacji czy zabawy intelektualnej, ale pewna ocena sytuacji, w której się znaleźliśmy. Należy się zastanowić, razem z Kołakowskim, czy można stworzyć racjonalny kodeks normatywny bez odwoływania się do autorytetu Boga, którego istnienia nie sposób udowodnić, albo też wrodzonej intuicji moralnej, która można obalić. Wydaje się, że pomysł Kanta jest najbardziej odważny, ale - zdaniem Kołakowskiego - i tak niedoskonały. Według niego imperatyw kategoryczny ,[...] nie ma logicznego czy psychologicznego ugruntowania; mogę go odrzucić bez popadania w sprzeczność, a mogę

\footnotetext{
${ }^{15}$ T. Bartoś, Fakty i mity, „Znak” 2011/678.

${ }^{16}$ Por. L. Kołakowski, Jeśli Boga nie ma... O Bogu, Diable, Grzechu i innych zmartwieniach tak zwanej filozofii religii, Kraków 1988, s. 171.

${ }^{17}$ Podobnego zdania jest H. Jonas, dla którego przywrócenie kategorii świętości warunkuje etykę, która z dnia na dzień ma coraz trudniejsze zadanie w obliczu powiększajacych się możliwości człowieka. Por. Hans Jonas, Etyka dla cywilizacji technologii, tłum. M. Klimowicz, Kraków 1996, s. 58.

${ }^{18}$ M. P. Markowski, Bez ostatecznej syntezy, „Tygodnik Powszechny”, „Apokryf” 43/18 (2002).

${ }^{19}$ L. Kołakowski, Czy diabet może być zbawiony, [w:] idem, Czy diabeł może być zbawiony i 27 innych kazań, s. 172-173

${ }^{20}$ L. Kołakowski, Jeśli Boga nie ma..., s. 171.
} 
też przyjąć za nakaz naczelny - lecz tylko na mocy arbitralnej decyzji - chyba że pojawia się on w kontekście kultu religijnego"21.

\section{POJĘCIE TABU}

Przekonania moralne mają inny status niż przekonania empiryczne. Nawet gdyby ludzie doszli do wniosku, że takie zdanie, jak „Tortury są złe”, jest prawdziwe, to nic by im nie przeszkadzało prawdę tę ignorować; podobnie jak wiele różnych prawd. Jednak przekonania moralne nie rodzą się z uznania prawdy albo fałszu, ale z poczucia winy, gdy je naruszamy. Tak więc wiedzę tę zdobyliśmy w inny sposób niż wiedzę dotyczącą rozróżnienia kolorów. Kołakowski zauważa, że na ten aspekt zwraca uwagę Biblia, nieco później Hegel, a ze współczesnych myślicieli Freud ${ }^{22}$. „Nasi prarodzice musieli uczynić zło, nim poznali, czym jest dobro; grzech przywiódł ich do wiedzy i uczynił ludźmi",23. Tak więc doświadczenie tabu pozwala na moralne rozróżnienie dobra i zła. Wiemy naprawdę, czym jest dobro, dopiero poznając, czym jest zło; a wiedzę taką możemy uzyskać, czyniąc je. Tak więc dopiero gwałt tabu daje nam wiedzę na temat tej fundamentalnej różnicy. „Sacrum odsłania nam się w doświadczeniu upadku” ${ }^{24}$. Warto także przypomnieć koncepcję Girarda, według którego kozioł ofiarny ${ }^{25}$ jest fundamentem cywilizacji, a sacrum i transcendencja sa konsekwencją i rezultatem zbiorowej przemocy $^{26}$. Odpowiedzialność za zabicie ofiary spoczywa na całej grupie, jednak winą obarcza się właśnie ofiarę, która jednocześnie staje się sacrum, ponieważ - zdaniem Girarda - ,przemoc i sacrum są nierozłączne”27. Według Kołakowskiego również pierwotne rozróżnienie między dobrem a złem wzięło się z poczucia winy, z naruszenia tabu. Tabu zaś jest ściśle powiązane z sacrum. Religia więc jest dla Kołakowskiego podstawą moralności, a także wartości moralnych.

Warto się zastanowić, czy Kołakowski może mieć rację, czy we współczesnej kulturze można w ogóle jeszcze mówić o tabu? Jednym z obszarów, w których mogliśmy jeszcze doszukać się świętości, była sfera śmierci. Wyrażała się ona w szacunku do ciał zmarłych, w ich nietykalności. Obecnie nie tylko powszechnie - i wydaje się, że jest to słuszne akceptowane są przeszczepy organów, sekcje zwłok, ale zauważalne jest coś jeszcze. Charakterystyczne jest to, że człowiekowi w momencie śmierci odbieramy należny mu szacunek. Choć Kołakowski nie kwestionuje potrzeby ingerencji medycznych, to jednak łączy $\mathrm{z}$ tym pewną obawę, że ciała ludzi będą traktowane jak fabryka części zamiennych $^{28}$. I choć kultura europejska wydaje się daleka od tego, to choćby Stany

\footnotetext{
${ }^{21}$ Ibidem, s. 207.

${ }^{22}$ Zdaniem Freuda: „Najpierw klan braci zajął miejsce hordy ojca i został utwierdzony przez więź krwi. Współczesne społeczeństwo oparte jest na współwinie popełnionej zbrodni, religia na świadomości winy $i$ wynikającej z niej skrusze, moralność zaś jest częściowo oparta na konieczności społecznej, a częściowo oparta na konieczności społecznej, a częściowo, na potrzebie zadośćuczynienia, którego domaga się świadomość winy" (Z. Freud, Totem i tabu, tłum. M. Poręba, R. Reszke, Warszawa 1997, s. 143). Zob. także Z. Freud, Kultura jako źródło cierpień, tłum. J. Prokopiuk, oprac. R. Reszke, Warszawa 1995.

${ }^{23}$ L. Kołakowski, Jeśli Boga nie ma..., s. 216.

${ }^{24}$ Ibidem, s. 216.

${ }^{25}$ Por. R. Girard, Kozioł ofiarny, Łódź 1987, s. 134.

${ }^{26}$ R. Girard, Sacrum i przemoc, t. 1, Poznań 1994, s. 120.

${ }^{27}$ Ibidem, s. 25.

${ }^{28}$ Por. L. Kołakowski, Cywilizacja na ławie oskarżonych, [w:] Cywilizacja na ławie oskarżonych, Warszawa 1989, s. 213.
} 
Zjednoczone są już w zdecydowanie bardziej niepokojącej sytuacji. Jest jeszcze jeden aspekt tej sprawy, który wydaje się Kołakowskiemu jest mniej ważny - krótko wspomina o tym w Obecności mitu. Pojęcie śmierci, jej doświadczenie, jest wypierane z naszego życia, ponieważ może być przyczyną naszego cierpienia. Uciekamy od tego zjawiska ${ }^{29}$, ,[...] nie w ten sposób jednak, by nieuchronność śmierci oswoić, ale tak, by zepchnąć ją z pola uwagi, usunąć z życia starcia z pytaniami ostatecznymi, dać się rozpuścić bez reszty każdorazowej bezpośredniości życia ${ }^{30}$.

Pojawia się pytanie, czy jest to powrót do pojęcia tabu, czy raczej całkowita z niego rezygnacja. Wydaje mi się, że raczej druga możliwość byłaby bardziej odpowiednia. Powodem, dla ktorego współczesny człowiek nie chce uczestniczyć w odejściu ostatecznym drugiej osoby, nie jest to, że jest to dla niego porażające lub że jest to świętość, przed którą czuje respekt i szacunek. Dzieje się tak raczej dlatego, że śmierć nie jest estetyczna, a ludzie przejawiają pod tym względem coraz większe potrzeby. Także dlatego, że nie chcemy mówić o tym, co jest dla nas przykre i krępujące. Żyjemy w kulturze, w której każda dziedzina życia jest udoskonalana. Biel jest jeszcze bielsza, radość jeszcze intensywniejsza, nie ma więc miejsca na niedoskonałości, czyli na śmierć.

Kolejną sferą tabu była seksualność człowieka. Tutaj nie ma żadnych wątpliwości. To, co kiedyś było otoczone religijną tajemnicą, dziś zmajduje się pod mikroskopem i na pierwszych stronach kolorowych czasopism. Moment inicjacji seksualnej czy poczęcia stanowiły, jak pisze Kłoczowski: ,[...] momenty działania potężnych sił sakralnych, dlatego wymagały rytualnego wprowadzenia i ochrony, bez których sfera seksu była niebezpieczna, ${ }^{31}$. Obecnie nie tylko przeżycie seksualne zostało oderwane od prokreacji, ale i inicjacja seksualna zostaje przeniesiona $\mathrm{z}$ intymnego otoczenia do różnych obcych nam miejsc. Nierzadko w dzisiejszych czasach defloracja odbywa się z pomocą lekarza i środków znieczulających. Okazuje się, że sytuacja ta różni się od pójścia do stomatologa jedynie tym, że jest jednorazowa. Co więcej, życie intymne $\mathrm{z}$ alkowy przeniosiono do mediów, wprowadzono liczne zasady, jakie kobieta i mężczyzna muszą spełniać. Przodują $\mathrm{w}$ tego rodzaju nowościach kolorowe czasopisma dla pań. Trudno mówić na tym gruncie jeszcze o tabu. Wydaje się, że pozostał jeszcze zakaz kazirodztwa czy niejedzenia ludzkiego mięsa. Choć wydarzenia z 2004 roku $^{32}$ oraz show zaproponowane w 2011 roku przez holenderską telewizję ${ }^{33}$ stawiają również przestrzeganie tych zasad pod znakiem zapytania.

Polscy publicyści mają nieco inny pogląd niż Kołakowski na temat tabu. Okazuje się, że do tych tematów zaliczają między innymi prywatność, życie seksualne, aborcję, feminizm, ateizm, historię, socjalizm, kapitalizm czy papieża. Mimo że twórcy artykułu powołują się na koncepcję Leszka Kołakowskiego, można odnieść wrażenie, że zmienili oni nie tylko kontekst rozważań, ale $\mathrm{i}$ ich sens. Tabu jest dla nich rodzajem zagrożenia wolności, a także stoi w konflikcie z demokracją i kulturą masową. Tabu określają też

\footnotetext{
${ }^{29}$ Por. J. Stecko, Bioetyka końca życia, [w:] Filozofia wobec XXI wieku, red. L. Gawor, Lublin 2004, s. $251 \mathrm{n}$.

${ }^{30}$ L. Kołakowski, Obecność mitu, Wrocław 1994, s. 105.

${ }^{31}$ J. A. Kłoczowski, Więcej niz mit, Leszka Kołakowskiego spory o religię, Kraków 1994, s. 293.

${ }^{32}$ W 2004 roku w Niemczech rozpoczął się proces mężczyzny, który drogą internetowa znalazł osobę chętną do tego, aby została zabita i zjedzona przez zabójcę, plan ogłoszenia został zrealizowany.

${ }^{33} \mathrm{~W}$ holenderskim programie telewizyjnym Króliki doświadczalne (Proefkonijnen) wyemitowanym 21.12.2011 roku prezenterzy sprawdzali smak ludzkiego mięsa, zjadając nawzajem części wykrojone przez chirurgów z własnych ciał na potrzebę eksperymentu. Choć program wzbudził liczne pytania dotyczące prawdziwości nagranych scen, nie zmienia to faktu łamania tabu.
} 
jako czynnik wyróżniający z ogromnej masy ludzi, „,...] tabu na przykład pozwala nam się wyodrębnić z ludzkiego morza: nie jemy wieprzowiny, jesteśmy Żydami; nie uprawiamy seksu przed ślubem, jesteśmy chrześcijanami; nie całujemy się w parku ani na ulicy $[\ldots]^{\prime 34}$. Wydaje się, że takie ujecie tematu nie wprowadza nas w obszar świętości i moralności.

Dla Kołakowskiego zbiór tabu stanowi o kulturze: ,[...] kultura bez tabu, jest kwadratowym kołem,35. Dlatego że obecność tabu jest nie tylko filarem życia religijnego, ale także systemu moralnego. W pojęciu kultury - zdaniem Kołakowskiego - ujawnia się związek dobra i zła z dziedziną sacrum. Nasuwa się pytanie, co się stanie z naszą kultura, jeśli - jak twierdzi Kołakowski - odczarowaliśmy tabu i ten proces nadal trwa. Wydaje się, że kultura bez tabu nadal będzie kultura, szczególnie w szerokim pojęciu tego słowa; jednak można się zgodzić z Kołakowskim, że będzie miała już zupełnie nowy wymiar. Być może pozostanie nam już wtedy tylko to, co przewidział Hobbes w Lewiatanie, policja chroniąca nas przed wzajemną agresją.

Pojawia się pytanie, co rozpoczęło ten proces sekularyzacji i desakralizacji świata. Czy jedynie kultura oświeceniowa ponosi winę? W tekstach Kołakowskiego można znaleźć różne odpowiedzi na tak postawiony problem. Po pierwsze procesie tym brała udział myśl oświecenia, a wynikało to $\mathrm{z}$ potrzeby zracjonalizowania wszystkich elementów życia człowieka i postulatu o możliwości samodoskonalenia. Po wtóre - myśl Marksa i wypływało to również z propozycji człowieka prawie doskonałego, niezależnego od sacrum, a także wpłynęła na ten proces filozofia Nietzschego, który ,[...] dopowiedział wszystko do końca: świat nie wytwarza sensu i nie wytwarza także różnicy między dobrem i złem, rzeczywistość jest bezcelowa i nie ma za nią żadnej innej ukrytej rzeczywistości, świat, jakim go widzimy, jest Ultimum, nie próbuje nam niczego powiedzieć, nie odsyła do niczego innego, wyczerpuje się sam $\mathrm{w}$ sobie $\mathrm{i}$ jest głuchoniemy"36. A jeśli wszechświat rzeczywiście jest głuchy, to nie ma znaczenia, czy człowiek ma dar mowy, bo jego mowa będzie tylko grą, którą się bawi. „Nada, nihil, nic oto ostatnie słowo i testament znikającego Boga, a i człowieka, który jest przyzwalającym świadkiem Jego odejścia. Mówił tak Hiob, Dawid Eklezjastes, Pascal, Dostojewski, Kierkegaard, a także Lukrecjusz, Schopenhauer, Nietzsche, Sartre, Camus, Céline i wielu innych" ${ }^{37}$. Wydaje się, że zaczynem owej lawiny, którą dziś analizujemy była właśnie myśl oświecenia. Jednak zanegowanie oświecenia nie jest prostym rozwiązaniem, ponieważ wartość osiagnięć tej epoki jawi się nieco dwuznacznie. $Z$ jednej strony kultura oświeceniowa pozostawiła nam niechęć do religii, ale z drugiej nadała światu ogromne tempo rozwoju. Jego efektem są wszystkie udogodnienia, których nie tylko nie potrafimy, ale też nie chcielibyśmy się wyrzec. Nie potrafimy jednak przewidzieć ani kierunku, ani konsekwencji, jakie nam te zmiany przyniosą. Właściwie trudno mówić o jakichkolwiek ramach.

\footnotetext{
${ }^{34}$ Zespół autorów, Białe plamy, czarne dziury, Polskie tabu, czyli o czym nie mówimy otwarcie, „Polityka” 2003/25.

${ }^{35}$ L. Kołakowski, Jeśli Boga nie ma..., s. 214.

${ }^{36}$ L. Kołakowski, Cywilizacja na tawie oskarżonych, s. 205.

${ }^{37}$ L. Kołakowski, Jeśli Boga nie ma..., s. 231.
} 


\section{ZAKOŃCZENIE}

Mimo licznych głosów etyków przestrzegających przed różnymi konsekwencjami, nie można przewidzieć wszystkich potencjalnych zagrożeń. W historii istnieje wiele przykładów na to, że zwyrodniała wyobraźnia człowieka często przewyższa wszelkie obawy. Jak pisze Kołakowski, żyjemy więc w świecie dwuznacznym. Racjonalizmu propagowanego przez myślicieli oświeceniowych nie powinno się traktować, jakby był zła idea. Hasło sapere aude ${ }^{38}$ dzisiaj nie jest już niepotrzebne. Jednak należy mieć świadomość, że istnieją problemy, z którymi rozum sobie nie poradzi, a w swojej pysze najprawdopodobniej nie będzie chciał przyznać się do porażki.

Tak więc w konsekwencji wydajemy się rozczarowani zarówno tym, co straciliśmy, jak i tym, co zyskaliśmy dzięki oświeceniu. Rozczarowani bezsilnością tradycji, jak i zadowoleniem nią, religią i uwolnieniem od niej; filozofią, podobnie jak światem, w którym osłabły metafizyczne poszukiwania; utopiami, a także stratą utopijnego myślenia; technika, którą doświadczamy równocześnie jako fascynującą i odpychająca. „Jesteśmy przekarmieni, lecz nigdy nie nasyceni” ${ }^{39}$.

\section{LITERATURA:}

[1] Audinet J., Religia, miejsce pojawienia się odmienności, [w:] Encyklopedia religii świata, Warszawa 2002.

[2] Bartoś T., Fakty i mity, „Znak” 2011/678.

[3] Bell D., Powrót sacrum Tezy na temat przyszłości religii, Znak” 1983/9.

[4]Białe plamy, czarne dziury, Polskie tabu, czyli o czym nie mówimy otwarcie, „Polityka” 2003/25.

[5] Freud Z., Kultura jako źródto cierpień, Warszawa 1995.

[6] Freud Z., Totem i tabu, Warszawa 1997.

[7] Girard R., Kozioł ofiarny, Łódź 1987.

[8] Girard R., Sacrum i przemoc, Poznań 1994.

[9] Heidrich Ch., Leszek Kolakowski, Zwischen Skepsis und Mystik, Verlag Neue Kritik Heidrich, Frankfurt am Mein 1995.

[10] Jonas H., Etyka dla cywilizacji technologii, tłum. M. Klimowicz, Kraków 1996.

[11] Kłoczowski J. A., Więcej niż mit, Leszka Kołakowskiego spory o religię, Kraków 1994.

[12] Kołakowski L., Czy diabeł może być zbawiony i 27 innych kazań, Londyn 1982.

[13] Kołakowski L., Cywilizacja na ławie oskarżonych, Warszawa 1989.

[14] Kołakowski L., Jeśli Boga nie ma ... O Bogu, Diable, Grzechu i innych zmartwieniach tak zwanej filozofii religii, Kraków 1988.

[15] Kołakowski L., Mini wykłady o maxi sprawach, t. III, Kraków 2000.

[16] Kołakowski L., Moje stuszne poglady na wszystko, Kraków 1999.

[17] Kołakowski L., Obecność mitu, Wrocław 1994.

[18] Kołakowski L., W salonie profesora Dudka, „Odra” 2003/6.

[19] Markowski M. P., Bez ostatecznej syntezy, „Tygodnik Powszechny”, „Apokryf” 43/18 (2002).

[20] Nowak P., Na poczatku byt Kołakowski, ,Tygodnik Powszechny” 2008/7.

[21] Rothenbuhler E. W., Komunikacja rytualna: od rozmowy codziennej do ceremonii medialnej, Kraków 2003

[22] Sieradzan J., Sacrum i profanum czy sacrofanum? Przemiany w rozumieniu sacrum we wspótczesnym świecie, „Polskie Towarzystwo Ludoznawcze” 2006/90, s. 13-36.

\footnotetext{
${ }^{38}$ L. Kołakowski, Nasza wesoła apokalipsa, [w:] Moje stuszne poglady..., s. 45.

${ }^{39}$ Ch. Heidrich., Leszek Kolakowski, Zwischen Skepsis und Mystik, Verlag Neue Kritik Heidrich, Frankfurt am Mein 1995, s. 303.
} 
[23] Stecko J., Bioetyka końca życia, [w:] Filozofia wobec XXI wieku, red. Gawor L., Lublin 2004. [24]

http://stacjakultura.pl/1,4,4946,Kosciol_na_sprzedaz_oblicza_desakralizacji_cz_I,1,artykul.html (dostęp: 10 III 2012).

\section{DO WE NEED SACRUM? CULTURE DIAGNOSIS IN TERMS OF LESZEK KOLAKOWSKI}

The article deals with the issues of secularization and desacralization of contemporary social life. It briefly describes the reasons for the division of reality into sacred and profane, referring to the analysis of texts by Leszek Kołakowski. The study is an attempt to summarize the consequences the blurring of distinctions leads to between that what constitutes the realm of the sacred and the profane.

Keywords: sacrum, profane, Leszek Kołakowski, culture.

DOI:10.7862/rz.2012.einh.12 